References

Allum, J.A.E. (1966) Photogeology and regional mapping. Pergamon Press.

Lattman, L. H. and Ray, R.G. (1965) Aerial photographs in field geology. Holt, Rinehart and Winston.

Rosenkrantz, A. and Pulvertaft, T.C.R. (in press) Cretaceous-Tertiary stratigraphy and tectonics in northern West Greenland. Amer.Ass. Petrol. Geol., Memoir 12.

\title{
PRELIMINARY NOTES ON THE TERTIARY LAVAS OF NORTHERN DISKO
}

\section{Asger Ken Pedersen}

A study on the lavas of northern Disko has recently been started. V. Münther has kindly lent the writer samples of Disko lavas collected on the earlier Nugssuaq expeditions. Apart from the pioneering work by Steenstrup (1882, 1901) very little has been published on the lavas from this region. Extensive literature exists on the rocks containing telluric iron but cannot be cited here.

During the summer of 1968 reconnaissance mapping and sample collection were undertaken in northern Disko from Vaigat in the north to Nordfjord and Stordal in the south. Both in the field and in the laboratory special attention was paid to lavas contaminated by reaction with pre-Tertiary sedimentary and metamorphic rocks.

The rocks underlying the volcanic sequence consist of Cretaceous sandstones and bituminous shales, and Precambrian gneisses and amphibolites. In Stordal the lavas can be seen to have buried hills consisting of weathered Precambrian metamorphic rocks. The beginning of the volcanism is characterized by the formation of subaqueous pillow breccias of picritic 
composition, varying in thickness from a few metres to several hundred metres. These breccias grade upwards into picritic lavas, which form a pile up to about $1 \mathrm{~km}$ in thickness. In the eastern part of the area a pillow breccia horizon is found in the middle of the picritic lava formation. The lavas are typically developed as rather thin pahoehoe flows. Two types can be distinguished. One type consists of resistant flows with olivine phenocrysts in a fine-grained groundmass. Another type consists of an easily weathering crystalline picrite basalt showing a considerable degree of internal differentiation. Vesicular veins up to $40 \mathrm{~cm}$ thick of olivine-free basalt are developed. In extreme cases more acid differentiates are found in the inner parts of these veins. Olivine-poor tholeiitic basalts are found locally in the sequence. A few flows show alkaline affinities with development of strongly purple-coloured titaniferous augites in residual cavities. Alkaline olivine basalts with small amounts of aegirine and dark mica in residual cavities have been found in the southern part of Hare $\phi$ en.

A series of thick resistant tholeiitic lavas more than $1.5 \mathrm{~km}$ in thickness overlies the picritic lava formation. At a single locality plagioclase-porphyritic tholeiitic pillow breccias were found at the base. The lavas are often columnar-jointed and have scoriaceous aa surfaces. The mean thickness of the flows is about $20-25 \mathrm{~m}$ and flows up to $50 \mathrm{~m}$ thick occur. The lavas are fine-grained aphyric or plagioclase- and augiteporphyritic tholeiitic basalts. Few flows have olivine as a third phenocryst phase.

Within both lava formations sequences of light greyish lavas occur; the number of flows varies from two to fifteen and the thickness of the sequences varies from $10 \mathrm{~m}$ to more than $100 \mathrm{~m}$. The sequences form valuable stratigraphic horizons and seem to be related to volcanic centres. In the picritic basalt formation two intervening sequences are found in the northern part of the area whereas three sequences are found in Stordal. In northern Kúgánguaq the upper of these sequences can be seen to have erupted from a number of small volcanoes and an assemblage with a few flows of olivine-poor and olivine-free tholeitic basalts was observed.

In the plagioclase-porphyritic tholeitic formation a group of volcanic centres is situated south of Gieseckes Dal. From these volcanoes lavas which are extremely contaminated by sediments and often contain 
telluric iron have been erupted. These volcanoes from north-west Disko were first observed by $V$. Münther (personal communication). A new centre was discovered by $\mathrm{G}$. Henderson during interpretation of aerial photos.

The lavas range petrographically from olivine-porphyritic bronzite basalts through aphyric and bronzite-porphyric basalts and basic andesites to andesites. In the contaminated lavas from the plagioclase-porphyritic tholeitic formation both orthopyroxene and plagioclase are found as phenocrysts. Some of the lavas contain telluric iron and sulphides, both of which often show gravitative settling. Varying amounts of xenoliths and xenocrysts were observed in the flows. The relative amounts of the various types of inclusions vary. In many of the lavas no xenoliths or xenocrysts were found. The xenoliths include gneisses, sandstones and bituminous shales and show varying degrees of melting, pyrometamorphism and equilibration with the magma. In the xenoliths the following pyrometamorphic minerals have been identified: clinopyroxene, cordierite, corundum, graphite, orthopyroxene, plagioclase, rutile, sillimanite or mullite, and spinel.

It has been confirmed that the well described "Anorthitfels" inclusions are modified bituminous sediments. This was suggested by Törnebohm (1878) and was the conclusion reached by Melson and Switzer (1966).

In Hammers Dal, at the upper boundary between sediment-contaminated andesites and tholeițic basalts, layers of acid tuffs and tuff breccias a few metres thick were found; these contain a large number of acid glassy blocks with phenocrysts of quartz, biotite and plagioclase. Some of the blocks contain xenocrysts of red garnet and orthopyroxene together with garnet-quartz intergrowth and are most likely the product of partial melting of Precambrian metamorphic rocks. V. Münther has earlier observed acid blocks in a conglomerate in Hammers Dal.

At the present early stage of investigation the following volcanic history can be sketched. During a period of regional plateau basaltic volcanism characterized by extensive outpouring of mantle-generated melts, magma was trapped at high levels in the Precambrian basement and in the Cretaceous sediments underlying the basalt formation. This magma differentiated and reacted with wall rocks and incorporated foreign material within it. Lava erupted from these local magma chambers. Depending on the original magma composition, on the degree of differentiation, on the degree of 
contamination and on the wall rock composition, the composition of erupted magma differed from magma chamber to magma chamber and from eruption to eruption. In a special case of contamination, magma containing telluric iron was formed by natural reduction processes. In another special case garnet-bearing acid rocks were formed.

\section{References}

Melson, W. G. and Switzer, G. (1966) Plagioclase-spinel-graphite xenoliths in metallic iron-bearing basalts, Disko island, Greenland. Amer.Min. Vol. 51, 664-676.

Münther, V. (1951) Grafitbasalten i NV-Disko. Medd. dansk geol. Foren. Bd. 12, 159 only.

Steenstrup, K. J. V. (1882) Om Forekomsten af Nikkeljern med Widmannstättenske Figurer i Basalten i Nord-Grфnland. Meddr Grфnland, Bd. 4, 113-132.

Steenstrup, K. J. V. (1901) Beretning om en Unders $\phi g e l s e s r e j s e$ til $\varnothing$ en Disko i Sommeren 1898. Meddr Grфnland, Bd. 24, 249-306:

Törnebohm, A.E. (1878) Über die eisenführenden Gesteine von Ovifak und Assuk in Grönland. Bih. K. svenska Vetensk. Akad. Handl., Bd. 4, No. $10,1-22$. 